\title{
ФРАЗЕОЛОГІЗМИ ТА НЕОФРАЗЕОЛОГІЗМИ В УКРАЇНСЬКОМУ ПОЛІТИЧНОМУ ДИСКУРСІ
}

\author{
СВІТЛАНА РОМАНЮК \\ Варшавський університет, Варшава - Польща \\ FRAZEOLOGIZMY I NEOFRAZEOLOGIZMY \\ W UKRAIŃSKIM DYSKURSIE POLITYCZNYM \\ SWITŁANA ROMANIUK \\ Uniwersytet Warszawski, Warszawa — Polska
}

STRESZCZENIE. W artykule przedstawiony został zarys funkcjonowania frazeologizmów i neofrazeologizmów w ukraińskim dyskursie politycznym używanych w celu wzmocnienia znaczenia własnych tez, postulatów, wniosków, a także, by przekonać przeciwnika politycznego. Przytoczono współczesne neofrazeologizmy powstałe w odpowiedzi na potrzebę bardziej przekonującego przekazu politycznego.

\section{PHRASEOLOGICAL AND NEO PHRASEOLOGICAL EXPRESSIONS IN UKRAINIAN POLITICAL DISCOURSE}

\author{
SVITLANA ROMANIUK \\ University of Warsaw, Warsaw - Poland
}

\begin{abstract}
The article outlines the usage of phraseological and neo phraseological expressions in the Ukrainian political discourse, which are generated in order to reinforce politicians' arguments, postulates and proposals, however, too often misused when trying to convince their political opponents. In the article, contemporary neo phraseological expressions, created for the sake of a more persuasive political message, are cited.
\end{abstract}

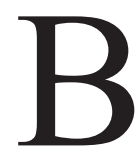

ивченню фразеологізмів присвячено чимало праць. Їхній колорит зазвичай найяскравіше виявляється в художньому, рідше - розмовному мовленні, яке вони збагачують й увиразнюють. Тому вчені частіше й досліджують згадані мовні одиниці в художніх творах.

Проте той матеріал, що став джерелом цього дослідження, містить не менше виразних прикладів, звичайно, іншого характеру — він має не естетичне спрямування, а часто зовсім протилежне: від пропагандного аж до агресивного. А це, нагадаємо, реалізується в межах офіційно-ділового стилю, аналізуючи який треба пам'ятати, що йому властива найбільша кодифікованість, тому вживання фразеологізмів і неофразеологізмів в офіційному мовленні повинно бути „необтяжливим”, адже воно „розпорошує” однозначність, відволікає від зосередженості на конкретному питанні, тим самим порушує закладену стильову функцію - інформувати й співпрацювати під час виконання службових обов'язків. У попередніх розвідках авторка вже розмірковувала про неправомірне вживання елементів розмовного стилю під час мовлення представни- 
ків українського парламенту ${ }^{1}$, а в ході подальшого аналізу політичного дискурсу простежуємо з'яву елементів мовлення, що вимагають детальнішого опису, саме тому фразелогізми й неофразелогізми стали об' єктом цього дослідження.

Для 3'ясування проблемного питання стосовно того, якою $є$ роль фразеологізмів і неофразеологізмів в політичному дискурсі, розгляньмо поняття, що є ключовими для метамови цієї статті. Такими є фразеологізм, неологізм і неофразеологізм як остання ланка в процесі збагачення певної конструкції новими семантичними відтінками.

Фразеологізм - це, як відомо, нарізнооформлений, але семантично цілісний і синтаксично неподільний мовний знак, що своїм виникненням і функціонуванням зобов'язаний фраземотворчій взаємодії одиниць лексичного, морфологічного та синтаксичного рівнів. Чітку дефініцію фразеологізму дає А. Грищенко, порівн.: „Фразеологізмом називається семантично пов'язане сполучення слів, що, на відміну від подібних до нього за формою синтаксичних структур (словосполучень або речень), не створюється в процесі мовлення відповідно до загальних граматичних і значеннєвих закономірностей поєднання слів, а відтворюється у вигляді фіксованої конструкції з властивим їй лексичним складом і значенням”, тобто „специфіку фразеологічної номінації як процесу вторинного семіосизу складає так зване 'переназивання': фразеологічна одиниця постає в результаті образного семантичного переосмислення, що приводить до перенесення відомої вже назви певної реалії на об'єкт семантичного переосмислення"3. Фразеологізми, що функціонують у політичному мовленні, хоча й іноді дещо видозмінені, зазвичай зрозумілі без додаткового пояснення й словникової довідки, напр. ${ }^{4}$ С Согодні між молотом і ковадлом не можна далі жити, кудись потрібно притулитися, до якогось берега, (бути в скрутному становищі, коли небезпека загрожує з обох боків); Якщо ховатимуться десь по норах, як шкідливі коти, знайдемо їх і там (боятися відповідальності); Я не знаю, скільки у фракції покидьків, $і$ не можу зазирнути кожному в душу. Я знаю, щзо люди, які клянуться на Біблії, повинні мати в собі щзось людське (намагатися зрозуміти чиїсь почуття, думки, сутність чогось); Я категорично засуджую дії тих, хто порушив права журналістів і підняв руку на свободу преcu (бити кого-небудь; туm - загрожувати існуванню чогось); Якщио изе буря, то це буря у склянці води. Це жодним чином не впливає на десятки мільйонів людей. Це політичний гламур (проблема, яка стосується невеликої кількості осіб, не надто важлива); Два місяці били байдики у парламенті, тепер на два місяиі поӥхали на Багами і Мальдіви. Де у Конституиії записано, щзоб законодавецьь міг чотири місяці відпочивати? (нічого не робити); У нас, нарешті, намітився конструктивізм у роботі. Опозиція трохи заспокойлася, вона розуміє, щзо треба працюювати на державу, вони вже й так по вуха у лайні (мати проблеми, бути у складній ситуації); Дійсно, народу набрид бедлам попереднього 'царювання’. Щоб виправити ситуацію, ї̈ просто перегнули (хаос, безладдя під

${ }^{1} \mathrm{C}$. Р оман юк, „Я прошу вас, послухайте. Криком ми ж нічого не допоможемо один одному”, або розмовний стиль в українському парламентському дискурсі. Реферат, IV Мiжнар. інтернет-конф. в Мюнхені, 1-4.11.2013 р.

2 А. П. Грищенко, Фразеологія, [в:] Сучасна украӥнська літературна мова, за ред. А. П. Грищенка, Київ 2002, с. 203.

3 В. М. В ас и льче н ко, Відображення украӥнськими обрядовими фразеологізмами статусної зміни зовнішності людини, [в:] „Українська мова”, 2010, № 1, с. 69.

${ }^{4}$ Приклади дібрані з : Електронний ресурс: http://ua.for-ua.com/analytics, http://www.pravda. com.ua (25.11.2012). 
час правління, в наведеному прикладі - недемократичного керування державою; перегинати палку — впадати в крайність, виявляти надмірну ретельність у чому-небудь $\left.{ }^{5}\right)$.

Щоб перейти до встановлення терміна 'неофразеологізм' (саме встановлення, оскільки це поняття є новим; словникової статті на визначення цього поняття немає досі в такому авторитетному джерелі, як Енциклопедія. Українська мова), потрібно пояснити значення терміна 'неологізм'. Визначення неологізму міститься в підручнику Сучасна украӥнська літературна мова, за яким неологізм - це слово, його окреме значення, вислів, що з'явилися в мові і новизна яких усвідомлюється мовцями (загальномовні), або вжиті тільки в якомусь акті мовлення, тексті чи мові певного автора. Вони зберігають елемент новизни й, відповідно, свій статус ,доки не стають узуальними, тобто загальновживаними, властивими усному й писемному мовленню якнайширших кіл носіїв літературної мови”, а „потреба в нових словах зумовлюється насамперед позамовними чинниками, зокрема соціальними й політичними змінами в суспільстві, розвитком науки і техніки, духовної культури тощо" 6 .

3 появою монографії Динамічні прочеси в сучасному украӥнському лексиконi пов'язуємо детальне обгрунтування термінів 'лексична іновація', 'неолексема', 'неологізм' і вживання їх як абсолютних синонімів. Крім того, в цій роботі подано критерії поділу лексичних інновацій на новотвори, неозапозичення та неосемантизми, розмежовано неозапозичення й іншомовні вкраплення, чи варваризми, виокремлено такі поняття неології, як морфемні та словотвірні інновації, визначено критерії відмежування неоформанта від неоморфеми, 3'ясовано обсяг поняття неосемантизм на тлі раніше вживаних понять і термінів ${ }^{7}$.

Отже, український лексикон є динамічною структурою, з розгорнутими інноваційними процесами, а неологізми збагачують мовлення на потреби мовної практики суспільства в умовах його розвитку й глобалізації. Незаперечним чинником при цьому є зростання ролі ЗМІ в сучасній суспільній комунікації, через які мовлення окремих осіб і суспільних груп також поповнюється і збагачується новими лексичними і фразеологічними одиницями. Вони з'являються спочатку в мовленні окремих осіб, а пізніше — в політичному й медіа-дискурсі, якот: немирягейт, гонгазегейт, тітушки, тушки, бандократія, зомбоящик, кучмізм, азаровщцина, кнопкодави й ін. Т. Печончик зазначає, що журналісти охоче вводять до мовлення нові слова, медійники „бувають не тільки творцями нових слів, а й тлумачами значень та активними ініціаторами впровадження в практику нових понять. Вони вводять терміни (напр., ‘девелопер', 'гаджет’) в контекст, дають їм визначення 'в полегшеному варіанті'” 8 .

Якщо перші два терміни - фразеологізм і неологізм - здебільшого не викликають застережень у науковців, є загальновизнаними в мовознавстві, то поняття неофразеологізму - нове й не до кінця обгрунтоване. Напр., В. Мокієнко наводить кілька варіантів називання нових фразеологічних одиниць: „не-

${ }^{5}$ Великий тлумачний словник сучасної украӥнськой мови, уклад. і голов. ред. В. Т. Бусел, Київ-Ірпінь 2009, с. 65; Словник української мови в 11 m., редкол.: акад. І. К. Білодід та ін., Київ 1975 , т. 6 , с. 150 .

6 А. П. Грищенко, Лексикологія, [в:] Сучасна украӥнська літературна мова, за ред. А. П. Грищенка, Київ 2002, с. 196.

${ }^{7}$ Н. Климе нко, С. Карпі лов сь ка, Л. Ки сл юк, Динамічні процеси в сучасному українському лексиконі, Київ 2008.

8 Лінгвіст Тетяна Печончик: „У ‘кравчучки', 'тітушка' $i$ 'кнопкодавів' $є$ чималі шанси потрапити до академічних словників”, інтерв’ю, автор — О. Хмельовська, [в:] „Український тиждень” Київ 17.10.2013, № 42, Електронний ресурс: http://tyzhden.ua/Culture/91716 (24.07.2013). 
ологічний фразеологізм”, „фразеологічна інновація”, „фразеологічна неологіка" 9, а для встановлення їхньої окремішності пропонує врахувати ступінь фіксації словниками, відчуття 'новизни' носіями мови, динамізацію вживання, актуалізацію, опозицію 'неологічне - архаїчне', соціофункціональні сфери їхнього існування і под. ${ }^{10}$, а визначення формулює в такий спосіб: „Фразеологічні неологізми — це не зареєстровані тлумачними словниками сучасних літературних мов стійкі експресивні звороти, що або створені заново, або актуалізовані в нових соціальних умовах, або створені трансформацією відомих уже паремій, крилатих слів і фразем, а також сполучення, запозичені з інших мов"11. Таке формулювання видається найбільш прийнятним і повним, зазначимо тільки, що природою появи цих фразеологічних одиниць (далі - ФО) стає реакція на зміни в соціальному, політичному та економічному житті суспільства, прогрес у широкому розумінні, внаслідок яких відбувається оновлення виражально-зображальних засобів мовлення. Проаналізуємо чинники з'яви ФО та їхню структуру. Формування фразеологізмів відбувається через виникнення первинного етимологічного образу, зумовленого: а) відображенням у національно-мовній свідомості типової предметно-поняттєвої ситуації; б) смисловими асоціаціями, що спричинюються фраземотворчою взаємодією лексичних компонентів ${ }^{12}$.

Натомість їхнє структурування можна подати як поділ на універсальні й специфічні одиниці, що мають відповідні характеристики. Універсальним (загальномовним) фразеологізмам притаманні відтворюваність і стабільність компонентного складу; специфічним - семантичні перетворення фраземотворчих компонентів, смислова цілісність та експресивно-емоційний характер фразеологічної семантики. Беручи до уваги встановлені розмежування, вважаємо, що неофразеологізми повинні належати до групи специфічних.

На основі встановленої Л. Пашинською класифікації, стисло перерахуємо ознаки неофразеологізмів: 1) високий ступінь функціонально-стилістичної і комунікативно прагматичної ефективності; 2) потреба створення негативної або позитивної оцінності описуваного явища, а також стилістичне завдання; 3 ) тенденція до мовної економії, що виявляється в прагненні мовців до вибору найефективніших комунікативних засобів, фіксації за допомогою відтворюваних і компактних мовних одиниць соціального досвіду носіїв мови; 4) широке використанням евфемізмів; 5) значне збільшення термінологічних словосполучень, професіоналізмів, що стають основою для творення неофразем; 6) незафіксованість у попередніх словниках ${ }^{13}$.

Зазначена дослідниця наголошує, що „фразеологічна неологізація належить до сфери вторинної номінації. Якщо лексичні неологізми та нові словосполучення виникають здебільшого в термінологічних системах, то неофразеологізми по-новому називають переважно не нове, а вже давно відоме поняття. Іншою ж особливістю ФН є їхня семантична прозорість і зрозумілість широкому колу

${ }^{9}$ W. Mokijenko, Проблемы европейской фразеологической неологики, [в:] Nowa frazeоlogia w nowej Europie. Новая фразеология в новой Европе. Neue Phraseologie im neuеn Europa. Stowo. Tekst. Czas. VI: Tezy referatów międzynarod. konf. nauk., Szczecin, 6-7.09.2001 r., pod red. H. Waltera, W. Mokijenki, M. Aleksiejenki, Greifswald 2001, s. 22-25.

${ }^{10}$ Ibidem, s. 22.

${ }^{11}$ Ibidem.

12 Украӥнська мова: Еничиклопедія, редкол.: В. М. Русанівський, О. О. Тараненко та ін., Київ 2000, с. 708.

13 Див.: Л. М. П аш и н с ь ка, Фразеологічні неологізми в сучасному українському мас-медійному дискурсі, Автореф. дис. канд. філол. наук, Київ 2011, с. 7-9. 
мовців та активне використання завдяки виразній мовній експресії'14, а щодо появи, ролі і вживаності ФО, то, на думку Л. Пашинської, „процеси фразеотворення найактивніші передусім у публіцистичному, зокрема мас-медійному, дискурсі, характерними ознаками якого є: (1) відображення мовного й культурного стану суспільства, його різноманітних цінностей; (2) функції повідомлення і впливу, аж до маніпулювання людською свідомістю; (3) кумулятивний ефект; (4) поєднання вербальної та візуальної інформації, що забезпечує ефективність сприйняття" ${ }^{15}$. Названі ознаки щодо процесу використання фразеологічних і неофразеологічних одиниць у публіцистичному дискурсі стосуються й мови політики, адже питання маніпулювання людською свідомістю належить передусім до проблематики аналізу політичного дискурсу. Четверта 3 названих ознак також є визначальною в аспекті інформування політиками своїх виборців - у цьому разі від ефективності сприйняття інформації залежить кінцевий результат - або перемога на виборах, або утримання при владі.

Фразеологізми-новотвори, типові для публіцистичного стилю, також є об'єктом аналізу досліження Н. Скиби ${ }^{16}$; відповідно до встановлених зазначеною авторкою критеріїв, запропоновано розмежовувати ФО, що слугують на позначення нових реалій дійсності, передусім власне просторічні, жаргонні, обсценні, суржикові.

Якщо ж йдеться про неоднорідну структуру неофразеологізмів, то Н. Скиба пропонує виділяти трансформовані ФО, що містять семантичні, структурні зміни, алюзійне цитування, контаміновані ФО. Таке структурування допомогає встановити не тільки природу окремої ФО, але й з'ясувати їі роль у контексті.

Спробуємо застосувати описаний підхід для аналізу окремих неофразеологізмів, вибраних із виступів українських політиків ${ }^{17}$. Особливої уваги заслуговують ФО, бо саме на фразеологічному рівні виразно виявляються національно-культурні особливості мовної системи, а оскільки „фразеологія — це та сфера мовної діяльності, де, з одного боку, в мовних фактах яскраво відбиваються етнопсихолінгвістичні особливості соціуму, а з другого, - чітко простежується вплив мови на формування його менталітету"18, вони відображають появу й репрезентують перетворення певних фактів, знаних спочатку окремій суспільній групі, пізніше - ширшому соціуму, напр.: Янукович лише верхівка айсберга олігархії, яка після помаранчевого стресу відновила своє всевладдя в Україні. Фразеологізм верхівка айсберга розбудований додатковим членом - олігархї, що звужує сферу впливів певної частини суспільства (у цьому разі - керівної) до взаємозалежності / співпраці або ін. із групою найбагатших людей у країні.

Словосполучення помаранчевий стрес варто зарахувати до неофразеологізмів, що номінує події після Помаранчевої революції 2004-2005 pр.; Рівень шуму такий високий тому, щзо у Раді зібралися украйнофоби і влаштовують політичний шабаш. Шабаш - за середньовічними повір'ями - нічне збіго-

${ }^{14}$ Там само, с. 7.

15 Там само, с. 8 .

${ }^{16}$ Н. Г. С к иба, Неофразеологізми в українському публіцистичному тексті, [в:] Електронний ресурс: http://www.slavistik.uni-muenchen.de/forschung/konferenz/t-inhaltsverzeichnis-2011.pdf, s. 204-211 (20.02.2012).

${ }^{17}$ Приклади дібрані з: Електронний ресурс: http://ua.for-ua.com/analytics (10.08.2013).

${ }^{18}$ В. В. Жа й в о р он о к, Етнолінгвістика та фразеологія, [в:] Украӥнська етнолінгвістика. Нариси, Київ 2007, с. 33. 
висько відьом, чортів, чаклунів і т. ін., що супроводжується диким розгулом ${ }^{19}$. Слово в тому ж значенні доповнене прикметником політичний: у такій формі цей фразеологізм означає невідповідну поведінку політиків у залі Верховної Ради України.

Наступні приклади є такими ж очевидними й промовистими й за умови мінімального знання українського історичного й політичного контексту не вимагають детального пояснення, напр.: Фундамент для нової Украӥни нікудишній. Сталін сидить у кожному з нас (йдеться про комуністичне минуле багатьох сучасних політиків); За рік уряду або за рік реформ ми отримали дійсно європейські ціни та африканські зарплати і пенсії (тобто надзвичайно низькі, що не відповідають стандартам європейської держави); ...уряд має сам нести повну відповідальність за те, щуо державні канали перетворюються на зливні бачки для піар смітмя, за все цее позорище в державному ефірі ${ }^{20}$ (називання 3МІ бачками для сміття означає, що медії $є$ залежними від влади, або певних олігархічних груп, розміщують неправдиву, сумнівну, замовну інформацію). Наведені приклади можуть слугувати зразком ФО на позначення нових політичних реалій, вони вимагають пояснення / доповнення тоді, коли 3'являються у відповідному тексті вперше або коли називають нові поняття, змінюючи своє первинне значення. В. Стахова вважає, що „зростання кількості фразем у наш час пов' язане зі змінами в соціальному, культурному, політичному житті українського суспільства. Більшість 3 них завдяки семантичній гнучкості значень активно приживається, взаємопереходячи $з$ одного мовного інвентарю до іншого. Хоч іноді фраземний склад динамічно поповнюється протягом певного невеликого періоду, оперативно віддзеркалюючи оцінку політичних процесів" 21.

Оскільки політичний дискурс має усталені правила щодо використання тих чи тих мовних засобів, його характеризує більша кодифікованість, ніж, скажімо, медійний, жаргонні й обсценні ФО повинні бути в ньому лише поодинокими й випадковими. Однак українська дискурсивна практика відходить від загальноприйнятої, і це дослідження засвідчує зовсім інше — варіативність і різнорідність уживання таких мовних одиниць, напр.: Вибачте за помилку. Не можу швидко вивчити всі 'злодійські малини' Януковича (крим., малина - 1) злодійський притон; 2) відсутність заборон, уседозволеність, привілля ${ }^{22}$ ); Тому щзо Ви щзе салага у Верховній Раді (жарг., зневажл., молодий і недосвідчений матрос $\left.{ }^{23}\right)$; Щоб, коли ми плануємо щось або говоримо, головне - щзоб ми шлеперами не стали, як дехто з наших попередників (крим., зневажл., шлепер - те саме, що лох, тобто жертва злочину, людина, яку легко обдурити $\left.{ }^{24}\right)$; Говорячи про те, щзо рівень злочинності у нормі, міністр Могильов бреше, як сивий мерин! (постійно брехати, порівняння з мерином - кастрованим жеребцем ${ }^{25}$ ); Врятуйте наші душі - вимкніть зомбоящик, візьміть книгу Андруховича, Забужко, Костенко, Загребельного, Іваничука, Дзюби, Гра-

${ }^{19}$ Словник украӥнської..., т. 11, с. 393.

${ }^{20}$ Електронний ресурс: http://ua.for-ua.com/analytics; http://www.pravda.com.ua/news/2011/08/ 15/6495125/ (20.08.2011).

${ }^{21}$ В . С т ах о в а, Поняттєво-виражальна сутність „фраземіки” в українському лінгвотермінологічному просторі, [в:] „Мандрівець” Тернопіль 2010, № 3, с. 78.

22 Л. С т а в и ць ка, Український жаргон: словник, Київ 2005, с. 211.

${ }^{23}$ Там само, с. 292.

${ }^{24}$ Там само, с. 377 , с. 205.

${ }^{25}$ Великий тлумачний словник..., с. 660. 
бовського, Шкляра, Мушкетика, Горліс-Горського, Вінграновського, Стуса. Вимкніть бидлячій шансон в авто й на роботі (крим., бидло - 1) корова; 2) про ув'язненого, який добросовісно працює; 3) психічно хвора людина ${ }^{26}$ ); Не треба чекати, як кажуть, коли грім ударить. Я вимагаю, Миколо Яновичу, негайно розглянути це питання і відпрацювати його по повній програмі (жарг.-крим., відбувати покарання за злочин протягом найдовшого з можливого і передбаченого законом терміну); Зараз 'програма максимум' опозииіїприйти до спільної думки щуодо парламентських виборів, щуоб ми один одному глотки не перегризли (непримиренно сваритися між собою або жорстоко розправлятися 3 ким-небудь, переважно в стані гніву, озлоблення тощо ${ }^{27}$ ); Чому у Віктора Андрійовича нічого не вийшло? Тому щзо буквально за кілька периих місяців президентства його всиновили олігархічні украӥнські клани (жарг., підпорядковуватися певній особі, групі); Мені грубо 'шиють' mi ж справи - про те, щуо я незаконно прийняв на роботу людину, яку можна приймати до 45 років, а їй було 47 (жарг., необгрунтовано звинувачувати когось у чомусь ${ }^{28}$, див. подібне клеїти - незаконно приписувати комусь чужу прови$\left.\mathrm{Hy}^{29}\right)$.

Під час аналізу фразеологізмів і неофразеологізмів вдалося підтвердити, що приклади їхнього вживання часто містять вербальну агресію щодо політичного суперника, в них виразно прослідковується домінуюча позиція мовця (зверхня, владна, керівна й ін.): Ця справа - це слушна нагода, цзе гарна нагода вкоротити поводок для деяких політиків, щзоб вони стали більш зручними для влади (перестати стримувати кого-небудь, дати волю комусь; послабити владу над ким-небудь, керівництво кимось); Я йому сказав: якщз ти зі свойми людьми не можеш знайти спільну мову, то бери шинель - іди додо$\boldsymbol{м y}$ (з військ. жарг., відправити когось, прогнати). Подібну вагу мають такі приклади: Нас ще півень не клюнув у голову. Півень уже над нами. Тільки дзьоб поставить - $і$ тоді буде біда; На жаль, Янукович прийшов з ментальністю неандертальця - саме так він сьогодні бачить, як конкурувати у політиці; Навіть, якби було бажання надіми вуздечку на 3MI, то изього ніхто не зможе зробити. Вони належать до власне просторічних неофразеологізмів, також небажаних у політичному дискурсі. Їхнє значення іноді вимагає пояснення, хоча інтенція виникає з контексту й зазвичай є зрозумілою: півень не клюнув у голову (залишатися при власному розумі), ментальність неандертальия (неосвічена, нерозумна людина), надіти вуздечку (змусити мовчати).

Загалом уважаємо, що політикові зовсім не обов'язково вдаватися до такого типу непарламентарного спілкування, можна вдало висловити свою думку за допомогою інших мовних одиниць. Порівняймо, скажімо, з прикладами вживання фразеологізмів, у яких чи постають образні переосмислення, чи „узагальнення набирають суто раціонального, прагматичного характеру, що виявляється в логічних, інтелектуальних умовисновках або в строгій констатації того або того факту"зо: Якщз хтось вважає, щзо влада йому впала на голову, як шапка Мономаха, і можна не думати щзодня про те, щзо ти зробив доброго для людей, то негайно по шапці отримає (зненацька, несподівано отримати; відповідати за негідні вчинки, неправильні дії); Із Мельниченка, як із рваної

\footnotetext{
26 Л. С т а в и ц ь к а, зазн. джерело, с. 54.

${ }^{27}$ Словник української мови..., Київ 1975, т. 6, с. 156.

28 Л. С т а в и цька, зазн. джерело, с. 375.

${ }^{29}$ Там само, с. 175.

${ }^{30}$ В. В. Жай в о р он о к, зазн. джерело, с. 34.
} 
калоші, ллється все, щзо завгодно (говорити непотрібне, зайве); У лікарнях у нас санвузли не працюють або стелі і балкони валяться. Така робота нікому не потрібна. Не чекайте, коли грім вдарить (раптово й несподівано щось станеться); Розумію, щзо у міліиії є своя робота, але крім роботи, міліція повинна мати ще голову. I якщо мілічія не матиме голови $і$ олії в голові, то вона принесе Президентові велику шкоду (поводитися розумно, відповідально) ${ }^{31}$.

Слушною є думка О. Тихоненко, яка вважає, що „фразеологічні норми виявляються у вживанні фразеологізмів без спотворення їхнього змісту і будови, їм притаманні такі ознаки: постійність складу, непроникність структури, стійкість граматичної будови, суворо закріплений порядок слів"32. Не потрібно доводити, що неофразеологізми не мають вищеперелічених ознак, що іноді без пояснення, або уважного повторного прочитання речення, або й тексту усього виступу, як і без знання ситуаційного констексту (напр., поведінки й дій у сесійній залі, під час інтерв'ю тощо) важко встановити значення того чи того неофразеологізму. Це не вимагає додаткового пояснення. Натомість основне питання, що постає, це - для чого й чому політики сягають до таких засобів увиразнення своїх виступів. Тут варто покликатися на думку мовознавців. Приміром, А. Грищенко зазначає, що „на відміну від лексичних одиниць, у складі української фразеології переважають звороти з виразними експресивно-оцінними значеннями, внаслідок чого їх використовують для створення експресивного фону як в усному, так і в писемному мовленні”з3, а от „виникнення інноваційних і оновлення наявних фразеологізмів зумовлено як внутрішніми можливостями мови щодо розвитку й удосконалення іiі зображально-виражальних засобів, так і суспільними змінами - глибшим пізнанням довкілля, зростанням суспільної свідомості і прагненням мовців до стилістично гнучкішого висловлення своїх думок і почуттів" "34. На думку Н. Скиби, „поява великої кількості нових понять у зв'язку з розвитком технічних засобів у змінених соціально-політичних умовах зумовлює потребу номінації та образної оцінки явищ дійсності, характерних для нової епохи та появу власне нових ФО"35.

Отже, учасники українського політичного дискурсу використовують багатство виражальних засобів з метою по-новому, влучно охарактеризувати явища і факти довкілля. Іноді виходить не надто вміло, зате креативно. Звертаємо також увагу, що 'політичні новотвори' - відмінні від знаних фразеологізмів, а також ФО, вживаних в інших дискурсах, вони досить часто надто брутальні й агресивно спрямовані.

Услід за Сжи Бральчиком, який пише про неможливість і небажання вияву порозуміння між польськими політиками ${ }^{36}$, Агнєшка Кампка пояснює такий спосіб ведення політичної розмови тим, що „,W dyskursie politycznym dominuje dziś potrzeba wyrazistości, którą najłatwiej uzyskać przy pomocy brutalnego języka, widocznego przede wszystkim w sposobach określania przeciwników politycznych. Często ma on na celu całkowite wyeliminowanie ich z dyskusji, przez ośmieszenie,

${ }^{31}$ Приклади дібрані з: Електронний ресурс: http://ua.for-ua.com/analytics (2012-2013 p.).

${ }^{32}$ О. Т и х о н е н ко, Формування фразеології офіційно-ділового стилю украӥнської мови, [в:] Семантика мови і тексту, Матер. XI міжнар. наук.-практ. конф., Івано-Франківськ 2012, с. 606.

33 А. П. Грище н ко, зазн. джерело, с. 209.

34 Л. М. Пашин с ька, зазн. джерело., с. 6.

${ }^{35}$ Н. Г. С к и б а, зазн. джерело, с. 207.

${ }^{36} \mathrm{~J}$. B ra lc zyk, O języku polskiej polityki lat osiemdziesiatych i dziewięćdziesiatych, Warszawa 2003, s. 7 . 
odebranie wiarygodności, zdyskredytowanie"37. Саме тому політики використовують найрізноманітніші способи впливу на співрозмовника, а фразеологізми й неофразеологізми вживають для підсилення власних тез, думок, вагомішого переконання політичного супротивника.

Л. Пашинська наголошує, що „в сучасних публікаціях посилився критичний погляд на діяльність різних гілок владних структур, що й зумовило активізацію лексико-фразеологічних одиниць негативно-оцінного змісту"з8. Експресія й образність мають викликати відчуття важливості сказаного, натомість уживання негативно маркованих конструкцій спричиняє швидкий запланований ефект — обурення, незадоволення політиків, а відтак — резонанс у середовищі й суспільстві.

Підсумовуючи висловлене, зазначимо, що функції неофразелогізмів у політичному дискурсі - образно передати нові явища, назвати їх неординарно, але так, щоб це запам'яталося й викликало подив, захоплення, обурення, дискусію тощо. Усталені фразеологічні звороти не мають такої сили, як новотвори. Неологізми влучніші, оскільки містять сучасний контекст, інколи зрозумілий тільки вибраним, залежно від ступеню влучності / повторюваності вони входять до сучасного словника спочатку політика, а згодом, за умови його якісного перетворення в узусну одиницю, - до словника й пересічного носія мови.

\footnotetext{
${ }^{37}$ A. K a mpk a, Perswazja w jezzyku polityki, Warszawa 2009, s. 31.
}

38 Л. М. П аш и н с ь к а, зазн. джерело, с. 6. 